\title{
INFLUENCE OF RIPENING CONDITIONS ON SURVIVAL OF BRUCELLA MELITENSIS IN TRADITIONAL LIGHVAN CHEESE (EWE MILK CHEESE)
}

\author{
Mir-Hassan Moosavy ${ }^{1}$, Nassim Shavisi ${ }^{1}$, Ehsan Mostafavi ${ }^{2}$, Amir Mohammad Mortazavian $^{3 凶}$, \\ Hamid Sayevand ${ }^{4}$, Sara Sohrabvandi ${ }^{5}$, Nasim Khorshidian ${ }^{5}$ \\ ${ }^{I}$ Department of Food Hygiene and Aquatics, University of Tabriz, Tabriz, Iran \\ ${ }^{2}$ Department of Epidemiology, Pasteur Institute of Iran, Tehran, P.O. Box 13169-43551, Iran \\ ${ }^{3}$ Department of Food Science and Technology, National Nutrition and Food Technology Research Institute, \\ Faculty of Nutrition Sciences and Food Technology, Shahid Beheshti University of Medical Sciences, \\ Tehran, Iran. \\ ${ }^{4}$ Food and Drug Administration, Ministry of Health and Medical Education, Tehran, Iran \\ ${ }^{5}$ Department of Food Technology Research, National Nutrition and Food Technology Research Institute, \\ Faculty of Nutrition Sciences, Food Science and Technology, Shahid Beheshti University of Medical \\ Sciences, P.O. Box 19395-4741, Tehran, Iran. \\ mortazvn@sbmu.ac.ir
}

https://doi.org/10.34302/crpjfst/2021.13.3.10

\begin{tabular}{|c|c|}
\hline Article history: & ABSTRACT \\
\hline $\begin{array}{l}\text { Received: } \\
\quad 18 \text { January } 2020\end{array}$ & $\begin{array}{l}\text { In developing countries, brucellosis is a reported and in most of cases, } \\
\text { consumption of raw milk and traditional cheeses contaminated with }\end{array}$ \\
\hline $\begin{array}{l}\text { Accepted: } \\
21 \text { May } 2021 \\
\end{array}$ & $\begin{array}{l}\text { Brucella spp., especially } B \text {. melitensis, is the main cause of disease. The } \\
\text { aim of this study was to evaluate the effects of ripening conditions }\end{array}$ \\
\hline $\begin{array}{l}\text { Keywords: } \\
\text { Lighvan; } \\
\text { Brucella melitensis; } \\
\text { Ewe milk cheese; } \\
\text { Ripening; } \\
\text { Sodium chloride }\end{array}$ & $\begin{array}{l}\text { (ripening temperatures: } 4,9 \text { and } 14^{\circ} \mathrm{C} \text { and salt concentrations: } 8,12 \text { and } \\
15 \% \text { ) on survival of } B \text {. melitensis in traditional Lighvan cheese (a typical } \\
\text { Iranian brine-ripened cheese) manufactured with raw ewe's milk during } \\
150 \text { days of ripening. Results showed that the viable counts of } B \text {. melitensis } \\
\text { changed significantly ( } p<0.01 \text { ) as a function of storage temperature. } B \text {. } \\
\text { melitensis survived significantly better at } 4^{\circ} \mathrm{C} \text { and } 9^{\circ} \mathrm{C} \text { than } 14^{\circ} \mathrm{C}(p<0.01) \text {. } \\
\text { All of salt concentrations }(8,12 \text { or } 15 \% \mathrm{NaCl} \text { ) significantly }(p<0.001) \\
\text { affected the inactivation of pathogen. } B \text {. melitensis had been completely } \\
\text { eliminated at the end of ripening period ( } 150 \text { days). Our findings indicated } \\
\text { that the using of hurdle technology (the two limiting factor, namely } \\
\text { temperature and salt concentration), is a powerful tool to eliminate } B \text {. } \\
\text { melitensis in Lighvan cheese after at least } 5 \text { months of ripening. }\end{array}$ \\
\hline
\end{tabular}

\section{Introduction}

Lighvan cheese is the most popular and commonly consumed Iranian traditional cheese with a long history of manufacturing. It is traditionally manufactured in the Lighvan region located in the province of East Azarbaijan, northern-west of Iran. It is a white brined, semi-hard cheese with sour taste, pleasant and very specific flavor and crumbly texture. The cheese is made from raw ewe's milk or mixtures of ewe and goat milk (70/30). Based on traditional technique, the milk is coagulated by rennet (from abomasum of lambs or kids) and is offered for consumption after undergoing 3-12 months of ripening in brine. During ripening process, some changes in the cheese including physic-chemical changes as well as the production of antagonistic compounds by indigenous microbial flora, organic acid and other compounds, could decrease the growth of pathogens (Hanifian \& Khani, 2012).

There are many studies involving traditional cheeses manufactured with raw milk 
in different countries that illustrate the presence and/or survival of important pathogenic bacteria such as Staphylococcus aureus, Salmonella spp., Listeria monocytogenes and Escherichia O157:H7 (Pinto et al., 2009, Jakobsen et al., 2011). The similar pattern of pathogenic bacteria is relevant in Iran, but in our country, raw milk and milk products especially cheese made from unpasteurized milk of sheep and goats is widely recognised as an important source of Brucella spp. contamination and a vehicle of brucellosis (Akbarmehr, 2011).

Based on the reports of the Iranian Ministry of Health and Medical Education, brucellosis is a common disease in most regions of Iran (Zamani et al., 2011). Generally, the disease is serious food-borne infection and undulant fever, night sweats, strange odor and severe headache are common symptoms that can observe in patients. Raw milk and cheese manufactured from raw milk of ewe and goats that may harbor Brucella spp. (Seleem et al., 2010; Solera, 2010).

Using hurdle technology (temperature, salt concentration and time of ripening) may serve as potential effective methods to eliminate and or reduction of pathogens in raw milk cheeses (Al-Holy et al., 2012). The survival of important food-borne pathogens such as Yersinia entrocolitica (Hanifian \& Khani, 2012), Listeria monocytogenes and Salmonella typhimurium (unpublished observations) in Lighvan traditional cheese under various conditions of ripening has been investigated by several authors, but there is little information about the survival of $B$. melitensis. Therefore, in this context, the aim of present work was to evaluate the influence of ripening temperatures $\left(4,9\right.$ or $\left.14^{\circ} \mathrm{C}\right)$ and ripening salting $(8,12$ and $15 \%)$ on survival of B. melitensis in traditional Lighvan cheese manufactured with raw milk during 150 days of ripening.

\section{Materials and methods}

\subsection{Materials}

Rennet casein was obtained from Meito Sangyo Co., Ltd. (Tokyo, Japan). Brain Heart
Infusion (BHI) broth and Peptone Water were used from Merck Company (Darmstadt, Germany). Brucella Selective Supplement SR0083, Blood agar, dextrose solution and inactivated horse serum were used to prepare a Brucella selective medium. All these media were purchased from Oxoid Co., Ltd. (Hampshire, England).

\subsection{Strain and culture preparation}

Native B. melitensis biovar 1 isolated previously from raw milk was obtained from the Razi Institute for Serums and Vaccines (Tehran, Iran). The strain was maintained in BHI broth containing $25 \% \mathrm{v} / \mathrm{v}$ glycerol at $80^{\circ} \mathrm{C}$. For activating, two consecutive subcultures were incubated in BHI Broth at $37^{\circ} \mathrm{C}$ for $24 \mathrm{~h}$. This work was done in 3 replicates. The overnight culture (from the second subculture) was diluted to achieve an initial inoculation level of approximately $10^{5}$ colony forming units per millilitre $(\mathrm{CFU} / \mathrm{mL})$ of milk.

\subsection{Cheese manufacturing}

Lighvan cheese $(8.5 \mathrm{~kg})$ was made with raw milk obtained from Lighvan village, as shown Fig. 1. For this, the cheese milk was examined for the absence of B. melitensis contamination prior to the cheese preparation. A B. melitensis biovar 1 culture was added to Fresh (pH 6.6) raw whole ewe's milk after the milking stage and before starting the process of cheese manufacturing concentration of $10^{5}$ colony forming units per millilitre $(\mathrm{CFU} / \mathrm{mL})$.

\subsection{Ripening conditions}

Ripening of the cheese was carried out over a period of 150 days during which samples were taken every 10 days. Two factor experimental design was applied to study the effect of ripening conditions (three temperatures: 4,9 or $14^{\circ} \mathrm{C}$ ), (three concentrations of $\mathrm{NaCl}: 8,12$ or $15 \%$ ) on the survival of $B$. melitensis of the cheese. The experiment was done twice. 


\subsection{Microbiological analysis}

25 grams of each cheese was sampled with $225 \mathrm{~mL}$ of $0.1 \%$ peptone water in a stomacher bag. The sample was then homogenized in stomacher and diluted it ten-fold serial dilution for plate count enumeration. The plates were incubated at $37{ }^{\circ} \mathrm{C}$ for 6 days. After which colonies having the $2-7 \mathrm{~mm}$ diameter, are spheroid in shape, moist, slightly opalescent and translucent were counted.

\subsection{Statistical analysis}

The effects of ripening temperature, salting and time on the survival of $B$. melitensis were evaluated using SPSS (version 16.0) and by Analysis of variance (ANOVA) test. P-value less than 0.05 were considered statistically significant.

\section{Results and discussions}

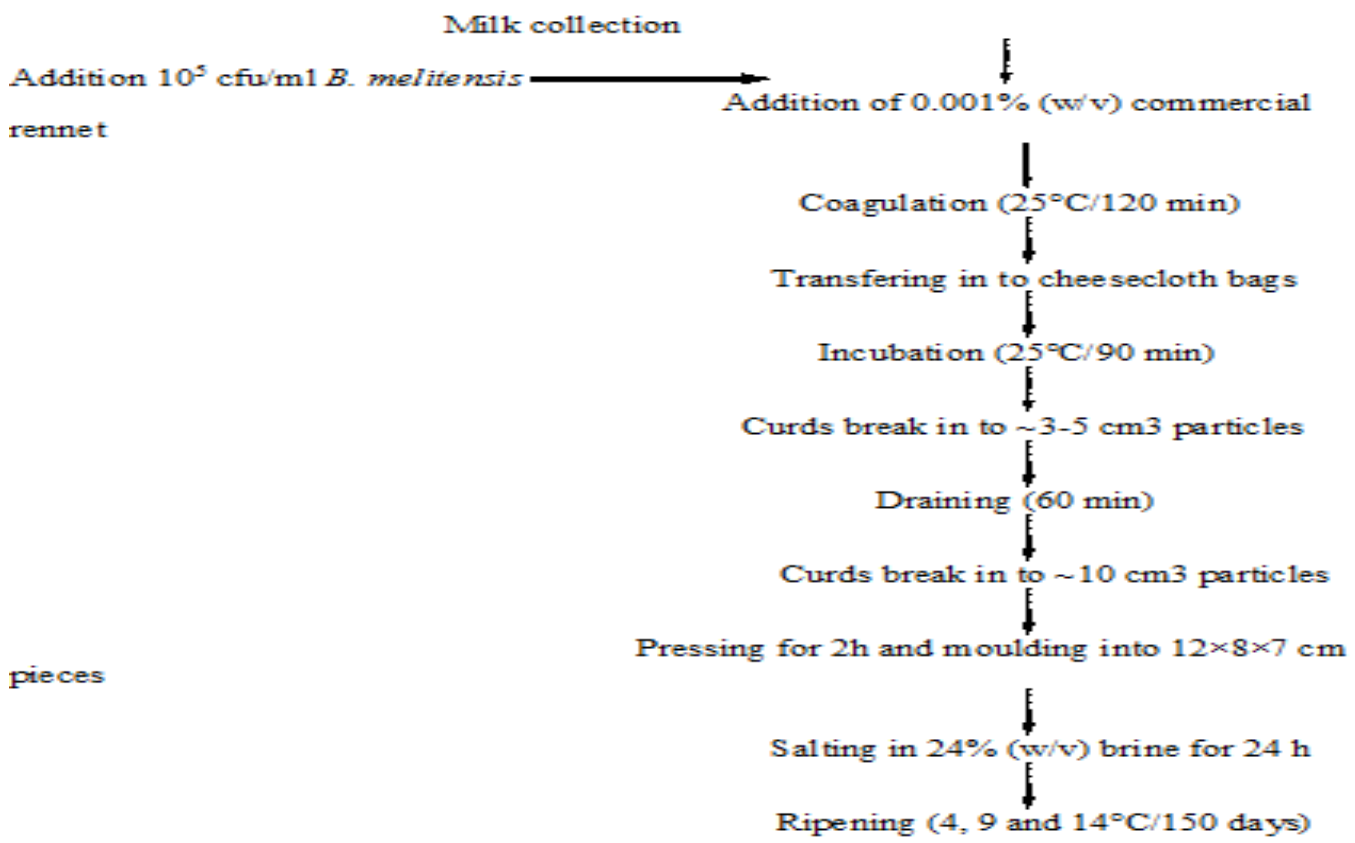

Figure 1. Schematic flowchart of Lighvan cheese production.

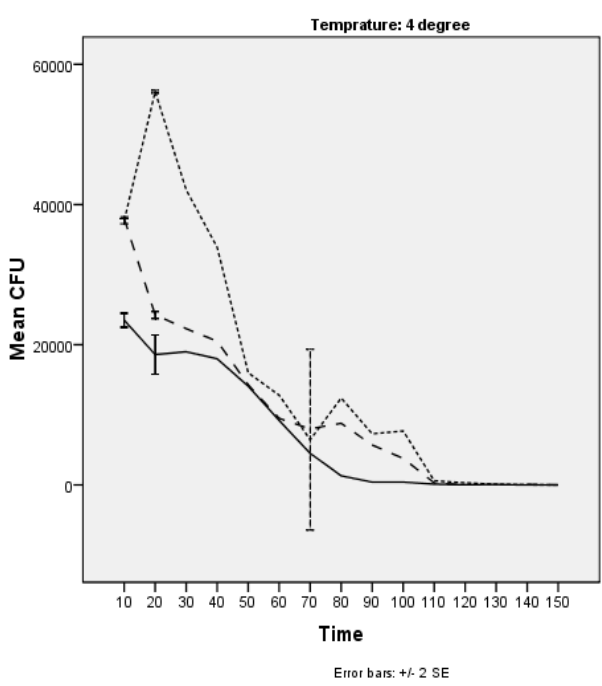

Figure 2. Survival of $B$. melitensis in traditional Lighvan cheese at $4^{\circ} \mathrm{C}$ during ripening.

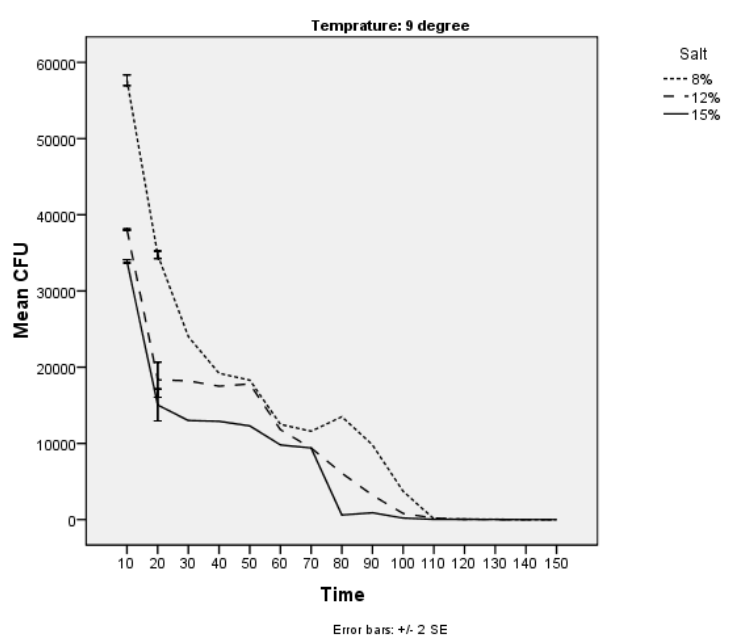

Figure 3. Survival of $B$. melitensis in traditional Lighvan cheese at $9^{\circ} \mathrm{C}$ during ripening. 
Figures 2, 3 and 4 indicated the survival of $B$. melitensis during 150 days of ripening period. B. melitensis was not isolated from any of milk samples. In detail, after inoculation, B. melitensis populations were reduced most rapidly during the first week of storage (between $34311 \quad( \pm 2624)$ and $25488 \quad( \pm 2965) \quad \log$ unit $)$ at three temperatures; after that they continually decreased, being below the detection limit $(1 \log \mathrm{CFU} / \mathrm{g})$ at the end of ripening. Temperature had significant effect on $B$. melitensis counts during ripening (Fig 2, 3 and 4). Analysis of variance indicated that numbers of surviving $B$. melitensis differed significantly $\quad(p<0.01) \quad$ with storage temperatures; it was demonstrated that $14^{\circ} \mathrm{C}$ was more effective than $9^{\circ} \mathrm{C}$ and $4^{\circ} \mathrm{C}$ $(P<0.01)$. The mean of the count of $B$. melitensis in traditional Lighvan cheese at $14^{\circ} \mathrm{C}, 9^{\circ} \mathrm{C}$ and $4^{\circ} \mathrm{C}$ was 13782,12794 and $7375 \mathrm{CFU} / \mathrm{g}$, respectively. According to results of Kruskal-Wallis, higher temperature enhanced the sensitivity of $B$. melitensis, suggested that temperature is a crucial factor in decrease of the bacterial populations $\quad(\mathrm{P}=0.079)$. Although $B$. melitensis were inhibited at the end of period (150 days) at the three temperatures, they survived in traditional Lighvan cheese for 130 days $\left(14^{\circ} \mathrm{C}\right)$ and 140 days $\left(9^{\circ} \mathrm{C}\right.$ and $\left.4^{\circ} \mathrm{C}\right)$. Inhibitory effects of $\mathrm{NaCl}$ concentration on the growth of $B$. melitensis are shown in Figures 5,6 and 7. The results obtained for $\mathrm{NaCl}$ concentrations demonstrated that all concentrations $(8,12$ and $15 \% \mathrm{NaCl})$ significantly $(p<0.001)$ affected the inactivation of pathogen (Fig 5, 6 and 7). Our results indicated that combined effect and interaction of temperature $/ \mathrm{NaCl}$ significantly $(p<0.001)$ affected the inactivation of pathogen. The results showed that time of ripening significantly influenced $(p<0.001)$ the survival of $B$. melitensis in Lighvan cheese.
In Iran, the incidence of B. melitensis in different types of dairy products particularly raw milk and milk products, especially cheese made from raw milk of sheep and goats, has been reported by several of researchers (Akbarmehr, 2011). To our knowledge, evaluation of potential survival of $B$. melitensis during production and ripening of traditional raw ewe's milk cheeses as well as the influence of ripening conditions on the fate of this bacterium in cheese such as Lighvan cheese has never been studied.

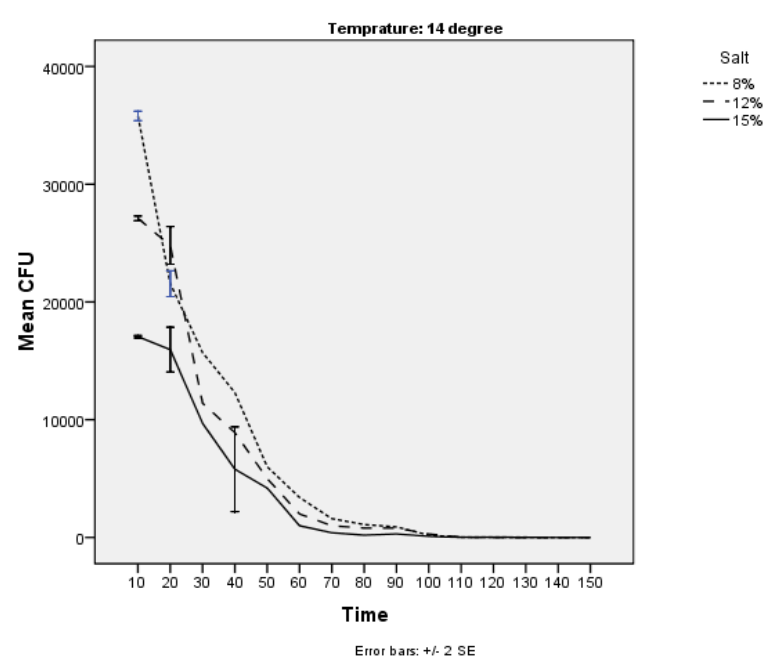

Figure 4. Survival of $B$. melitensis in traditional Lighvan cheese at $14^{\circ} \mathrm{C}$ during ripening.

According to results of this work, following ripening process, a significant reduction of $B$. melitensis count was observed. Several factors may contribute to reduction of this pathogen during ripening, such as presence of indigenous lactic acid bacteria including Lactococcus lactis and Streptococcus thermophilus (Hanifian \& Khani, 2012, Masoud et al., 2012, Navidghasemizad et al., 2009, Ong et al., 2009). The progressive production of some compounds such as bacteriocin, hydrogen peroxide and volatile compounds by lactic acid bacteria during ripening is well 
documented. A number of studies have shown the inhibitory effects of these compounds against food-borne pathogens (Tiganitas et al., 2009, Tamagnini et al., 2008). On the other hand, The $\mathrm{pH}$ from 6.6 to 7.4 is the best range for growth and survival of Brucella spp., therefore, acidic property $(\mathrm{pH})$ would be a key factor in decrease of survival and growth of Brucella spp. in dairy products such as cheese (Ozturkoglu et al., 2005, Zúñiga et al., 2005, Delbes et al., 2006; Falenski et al., 2011). A recent study by Aminifar et al. (2010) showed that the $\mathrm{pH}$ reduced from 60 to 90 days of Lighvan cheese storage on average from 5.69 to 4.65. Hanifian \& Khani (2012), revealed that $\mathrm{pH}$ reduction at the end of ripening process could be due to the natural lactic acid bacteria such as mesophilic lactobacilli, thermophilic lactobacilli and lactococci. The quantity levels of these bacteria were in their maximum levels at the end of ripening period. Therefore, acidic property was associated with a significant decrease of the bacterial count during ripening period of Lighvan cheese.

This study demonstrated that $B$. melitensis could survive 130 days (at 4 and $9^{\circ} \mathrm{C}$ ) and 140 days $\left(\right.$ at $14^{\circ} \mathrm{C}$ ) in traditional Lighvan cheese and this survival are regarded as a serious risk for consumer health. Based on our results, it seems that one of the main methods for complete elimination of $B$. melitensis is brining of Lighvan cheese for a long ripening period, at least 5 months.

With regards to the effect of temperature, it was found that $14^{\circ} \mathrm{C}$ is more effective than $9^{\circ} \mathrm{C}$ and $4^{\circ} \mathrm{C}(p<0.01)$. This result is in agreement with those achieved by Ingham et al. (2000), Tamagnini et al. (2005) and Callon et al (2011). Lower growth of most pathogens such as $B$. melitensis at low temperatures is due to alteration of fatty acid components in cell membrane of bacteria that interfere with membrane fluidity and lead to their death (Al-Holy et al., 2012).

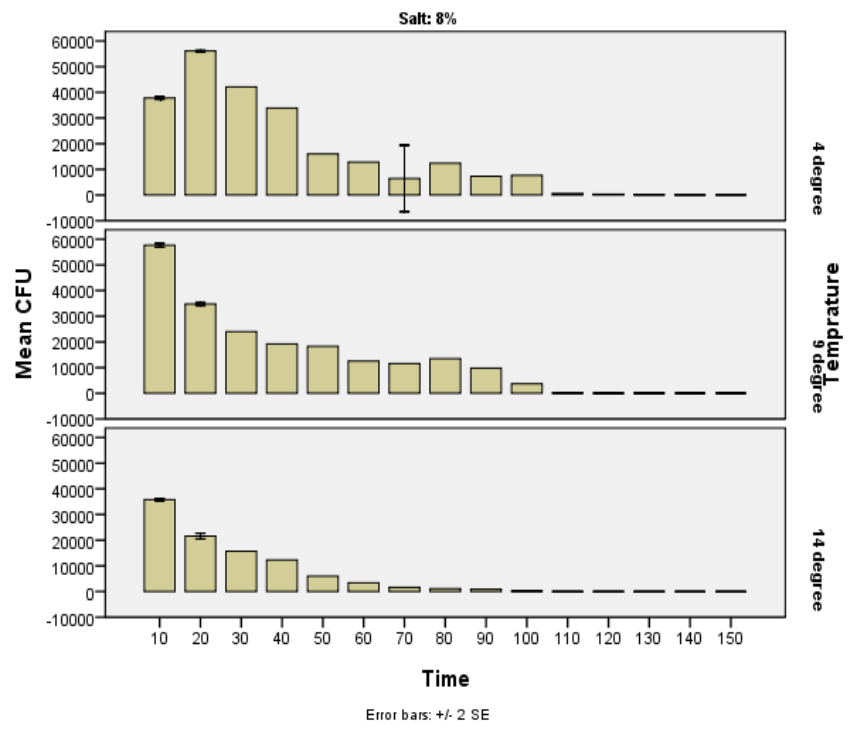

Figure 5. Effect of salt treatment (8\%) on the survival of $B$. melitensis in traditional Lighvan cheese at 4,9 and $14^{\circ} \mathrm{C}$ during ripening.

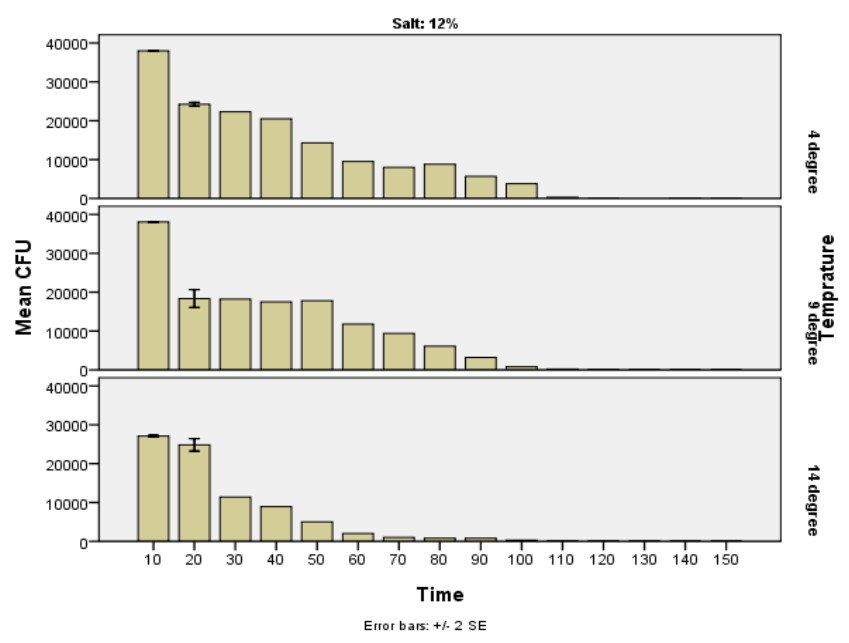

Figure 6. Effect of salt treatment (12\%) on the survival of $B$. melitensis in traditional Lighvan cheese at 4,9 and $14^{\circ} \mathrm{C}$ during ripening.

In addition to the temperature, the concentration of $\mathrm{NaCl}$ could affect the survival of pathogens during ripening period. Therefore, in the present study, effects of ripening salting $(8,12$ or $15 \%)$ on 
survival of B. melitensis also were evaluated. The results showed that the number of B. melitensis reduced drastically by all of concentrations (8, 12 and $15 \%$ $\mathrm{NaCl})(p<0.001)$. In addition, Aminifar et al. (2010) showed that the salt concentration was increased (approximately 3\%) during ripening of Lighvan cheese.

The observed trends for inactivation of pathogens with increasing of osmotic stress posed by $\mathrm{NaCl}$ in the present study are in agreement with those achieved by Ozturkoglu et al. (2006) on Listeria innocua during manufacture and storage of Turkish White Cheese in which the authors indicated the number of listeria cells drastically reduced following salt treatment.

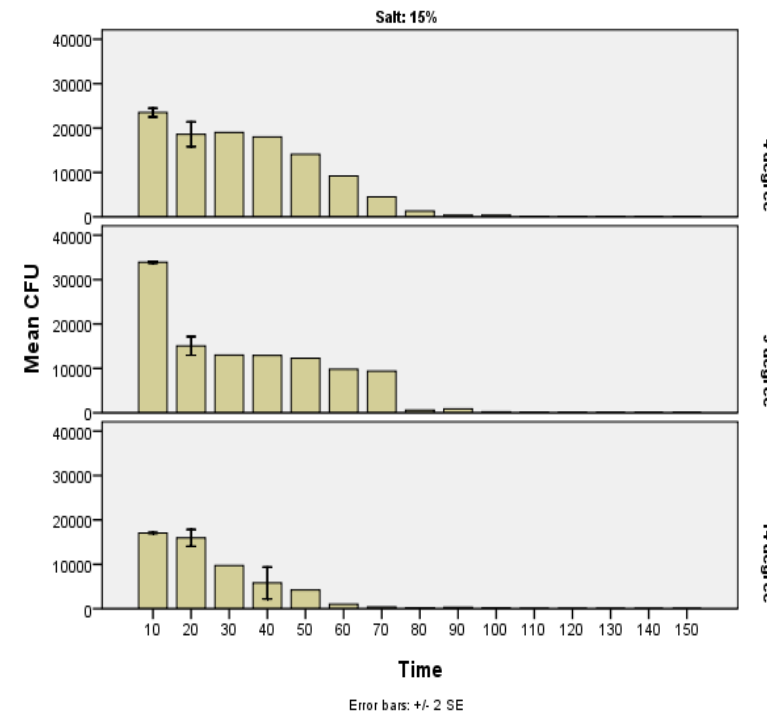

Figure 7. Effect of salt treatment (15\%) on the survival of $B$. melitensis in traditional Lighvan cheese at 4,9 and $14^{\circ} \mathrm{C}$ during ripening.

\section{Conclusions}

It can be concluded that the number of B. melitensis cells declined drastically during ripening days and eliminated at the end of ripening, but survival of $B$. melitensis during ripening under adverse conditions such as high salt concentrations and high temperatures along with high contamination of raw milk and consequently traditional
Lighvan cheese with mentioned bacteria could be a risk for consumer health. Therefore, additional studies are needed to develop rapid methods for detection of $B$. melitensis in such products. In addition, molecular studies are required to fully understand the survival of $B$. melitensis in order to complete elimination of this pathogen. Further investigations are also required to assess the effects of ripening temperatures and ripening salting on sensorial properties of Lighvan cheese.

\section{References}

Akbarmehr, J. (2011). The prevalence of Brucella abortus and Brucella melitensis in local cheese produced in Sarab city, Iran and its public health implication. African Journal of Microbiology Research, 5 (12), 1500-1503.

Al-Holy, M.A., Al-Nabulsi, A., Osaili, T.M., Ayyash, M.M., Shaker, R.R. (2012). Inactivation of Listeria innocua in brined white cheese by a combination of nisin and heat. Food Control, 23(1), 4853.

Aminifar, M., Hamedi, M., Emam-Djomeh, Z., Mehdinia, A. (2010). Microstructural, compositional and textural properties during ripening of Lighvan cheese, a traditional raw sheep cheese. Journal of Text Study, 41(4), 579-593.

Callon, C., Picque, D., Corrieu, G., Montel, M.C. (2011). Ripening conditions: A tool for the control of Listeria monocytogenes in uncooked pressed type cheese. Food Control, 22 (12), 1911-19.

Delbes, C., Alomar, J., Chougui, N., Martin, J.F., Montel, M.C. (2006). Staphylococcus aureus growth and enterotoxin production during the manufacture of uncooked, semihard cheese from cows' raw milk. Journal of Food Protection, 69 (2), 2161-2167. 
Falenski, A., Mayer-Scholl, A., Filter, M., Göllner, C., Appel, B., Nöckler, K. (2011). Survival of Brucella spp. in mineral water, milk and yogurt. International Journal of Food Microbiology, 145 (1), 326-330.

Jakobsen, R.A., Heggebø, R., Sunde, E.B., Skjervheim, M. (2011). Staphylococcus aureus and Listeria monocytogenes in Norwegian raw milk cheese production. Food Microbiology, 28 (3), 492-496.

Hanifian, S., Khani, S. (2012). Fate of Yersinia enterocolitica during manufacture, ripening and storage of Lighvan cheese. International Journal of Food Microbiology, 156 (2), 141-146.

Ingham, S.C., Su, Y.C., Spangenberg, D. (2000). Survival of Salmonella typhimurium and Escherichia coli O157:H7 in cheese brines. International Journal of Food Microbiology, 61 (1), 73-79.

Masoud, W., Vogensen, F.K., Søren, L., A1Soud, W.A., Sørensen, S.J., Jakobsen, M. (2012). The fate of indigenous microbiota, starter cultures, Escherichia coli, Listeria innocua and Staphylococcus aureus in Danish raw milk and cheeses determined by pyrosequencing and quantitative real time (qRT)-PCR. International Journal of Food Microbiology, 153 (1-2), 192202.

Navidghasemizad, S., Hesari, J., Saris, P., Nahaei, M.R. (2009). Isolation of lactic acid bacteria from Lighvan cheese, a semihard cheese made from raw sheep milk in Iran. International Journal of Dairy Technology, 62 (2), 260-264.

Ong, L., Shah, N.P. (2009). Probiotic Cheddar cheese: Influence of ripening temperatures on survival of probiotic microorganisms, cheese composition and organic acid profiles. $L W T-$ Food Science Technology, 42 (7), 1260-1268.
Ozturkoglu, S., Gurakan, G.C., Alpas H. (2005). Behavior and control of Listeria innocua during manufacture and storage of Turkish White Cheese. European Food Research Technology, 222 (5-6), 614-621.

Soares, P.M., de Carvalho, A.F., dos Santos Pires, A.C., de Paula, J.C.J., Sobral, D., Magalhães, F.A.R. (2009). Survival of Listeria innocua in Minas Traditional Serro cheese during ripening. Food Control, 20 (2), 1167-1170.

Seleem, M.N., Boyle S.M., Sriranganathan, N. (2010). Brucellosis: A re-emerging zoonosis. Veterinary Microbiology, 140 (3-4), 392-408.

Solera, J. (2010). Update on brucellosis: therapeutic challenges. International Journal of Antimicrobial Agents, 36S (1), S18-S20.

Tamagnini, L.M., de Sous, G.B., Gonzalez, R.D., Budde, C.E. (2008). Behavior of Enterobacter amnigenus and Salmonella typhimurium in Crottin goat's cheese: Influence of fluctuating storage temperature. Small Rumin Research, 76 (3), 177-182.

Tamagnini, L.M., de Sousa, G.B., Gonzalez, R.D., Revelli, J., Budde, C.E. (2005). Behavior of Yersinia enterocolitica and Salmonella typhimurium in Crottin goat's cheese. International Journal of Food Microbiology, 99 (2), 129- 134.

Tiganitas, A., Zeaki, N., Gounadaki, A.S., Drosinos, E.H., Skandamis, P.N. (2009). Study of the effect of lethal and sublethal $\mathrm{pH}$ and aw stresses on the inactivation or growth of Listeria monocytogenes and Salmonella Typhimurium. International Journal of Food Microbiology, 134 (1-2), 104-112.

Zamani, A., Kooraki, S., Mohazab, R.A., Zamani, N., Matloob, R., Hayatbakhsh, M.R., Raeeskarami, S.R. (2011). Epidemiological and clinical features of 
Brucella arthritis in 24 children. Annal Saudi Medicine, 31 (3), 270-273.

Acknowledgment

The authors would like to acknowledge the financial support from Food and Drug Administration of Iran, Shahid Beheshti University of Medical Sciences and Tabriz University of Medical Sciences. 